\title{
BIOCHEMICAL NUTRITIONAL PROFILE OF LIVER CIRRHOSIS PATIENTS WITH HEPATOCELLULAR CARCINOMA
}

\author{
Gabriela Zanatta PORT, Kalinca OLIVEIRA, Jonathan SOLDERA and \\ Cristiane Valle TOVO
}

\begin{abstract}
Context - Liver cirrhosis patients with hepatocellular carcinoma present nutritional alterations and metabolic disorders that negatively impact the prognosis. Objective - The objective is to identify alterations in the metabolism of macro and micronutrients among liver cirrhosis patients with and without hepatocellular carcinoma and their relation to the Child-Turcote-Pugh score and Barcelona Clinic Liver Cancer staging. Methods - Analytical transversal study, with 31 hepatocellular carcinoma patients and 48 liver cirrhosis patients. Laboratorial exams were carried out. The existence of an association between the biochemical parameters and the disease severity as well as the presence of hepatocellular carcinoma was assessed. Results - The metabolic-nutritional profile of liver cirrhosis patients caused by the hepatitis $\mathrm{C}$ virus and hepatocellular carcinoma showed alterations, specifically the lipid (total cholesterol, HDL and triglycerides), protein (albumin, creatinine and uric acid), iron (transferrin, iron and ferritin saturation), hematocrit and hemoglobin, zinc and B12 vitamin profiles. There is a relation between nutritional biochemical markers and the Child-Turcote-Pugh, as well as Barcelona Clinic Liver Cancer staging. Conclusion - Considering the existence of alterations in the metabolism of nutrients in liver cirrhosis patients with and without hepatocellular carcinoma, and also that conventional nutritional assessment methods present limitations for this population, the biochemical laboratorial exams are valid to complement the diagnosis of the nutritional state in a quick and practical manner.
\end{abstract}

HEADINGS - Liver cirrhosis. Hepatocellular carcinoma. Malnutrition. Nutritional assessment. Hepacivirus.

\section{INTRODUCTION}

The liver is responsible for essential functions in nutrient absorption, metabolism, storage, transportation, and activation ${ }^{(21)}$.

In liver cirrhosis (CI) patients, the distortions of hepatic parenchyma architecture result in the progressive loss of the hepatic form and function, compromising, in varied degrees, the nutritional state and body homeostasis of this population ${ }^{(10)}$.

Protein-energy malnutrition (PEM) has been described in $60 \%$ to $100 \%$ of patients with decompensated cirrhosis and in at least $20 \%$ of patients with compensated cirrhosis ${ }^{(16)}$. Patients with hepatocellular carcinoma (HCC) present increased energy expenditure, malnutrition, weight loss and $\operatorname{cachexy}^{(7,40)}$.

Given that malnutrition has an important role in hepatic injury pathogeneses and leads to a negative impact on the prognosis ${ }^{(7,36)}$, this study aimed to observe the profile of some macro and micronutrients among cirrhotic patients with and without HCC.

\section{Patients}

An analytical transversal study was performed. The study population consisted of a group of patients with liver cirrhosis without HCC, whose etiology is the hepatitis $\mathrm{C}$ virus (HCV); and a group of $\mathrm{HCV}$-related cirrhosis patients and HCC, who attended the Hepatology ambulatory of Santa Casa Hospital Complex, a tertiary attendance Hospital in Southern Brazil.

The study population included consecutive patients over 18 years of age.

Exclusion criteria were defined as patients with diabetes mellitus diagnosed through the American Diabetes Association (ADA) criteria( ${ }^{(2)}$, active alcoholics, patients with cirrhosis not caused by HCV and co-infected with the human immunodeficiency virus; patients could not have had digestive hemorrhage in the 6-month period prior to inclusion in the study.

\section{METHODS}

The patients were interviewed, and demographic data (age, gender), the body mass index (BMI) ${ }^{(42)}$ and

Declared conflict of interest of all authors: none

Pós Graduação do Curso de Hepatologia, Universidade Federal de Ciências da Saúde de Porto Alegre - UFCSPA, Porto Alegre, RS, Brasil.

Correspondence: Gabriela Zanatta Port. Rua Professor Freitas Cabral, 370, 1003. CEP: 90690-130 - Porto Alegre, RS, Brasil. Email: gabriela.port@hotmail.com 
the presence of ascites were assessed. The following laboratorial tests were performed: glucose, total cholesterol, HDL cholesterol, triglycerides, total proteins, albumin, creatinine, uric acid, transferrin saturation, iron, ferritin, hematocrit, hemoglobin, copper, zinc, magnesium, B12 vitamin, and folic acid. All exams were carried out in accordance with the routine procedures of the central laboratory of Santa Casa Hospital Complex, a tertiary attendance Hospital in Southern Brazil.

The HCV infection diagnosis was defined by the positive result of the anti-HCV antibody (ELISA III test) confirmed by the polymerase chain reaction (PCR).

Hepatic cirrhosis was diagnosed through clinical and laboratorial methods, image, endoscopy and histopathological exams, when needed. The patients were classified according to the Child-Turcot Pugh score (CTP) ${ }^{(31)}$.

Hepatocellular carcinoma diagnosis was established according to the Barcelona Clinic Liver Cancer (BCLC) and American Association for Study of Liver Disease (AASLD) group criteria ${ }^{(5)}$.

The project was submitted to and approved by the Ethics Committee of Santa Casa Hospital Complex and all patients signed an Informed Consent Term.

\section{Statistical Analysis}

Pearson's chi-square test was used to assess the association between the qualitative variables, and the adjusted residual test was carried out when necessary. Spearman's correlation coefficient was used to assess the association between the biochemical parameters and the disease severity. To compare the means, t-Student's test for independent samples was applied. In cases of asymmetry, Mann-Whitney's test was used. Values were considered significant if $P \leq 0.05$.

\section{RESULTS}

Sample characterization is presented in Table 1. There were more CTP-A patients in the group CI, and more CTP$\mathrm{C}$ in the group HCC. The patients from group HCC were significantly younger $(P=0.027)$. There was no significant difference concerning the BMI and presence of ascites.

TABLE 1. Sample characterization

\begin{tabular}{|c|c|c|c|}
\hline Variables & $\begin{array}{l}\text { Group HCC } \\
\quad(\mathrm{n}=31)\end{array}$ & $\begin{array}{c}\text { Group CI } \\
(\mathrm{n}=48)\end{array}$ & $P$-value \\
\hline Age (years) - Mean \pm SD & $56.0 \pm 7.6$ & $60.7 \pm 10.8$ & 0.027 \\
\hline Gender - n (\%) & & & 0.432 \\
\hline Male & $21(67.7)$ & $27(56.3)$ & \\
\hline Female & $10(32.3)$ & $21(43.7)$ & \\
\hline CHILD - n $(\%)$ & & & 0.013 \\
\hline A & $19(61.3)$ & $41(87.2)^{\#}$ & \\
\hline $\mathrm{B}$ & $09(29.0)$ & $06(12.8)$ & \\
\hline C & $03(9.7)^{\#}$ & $0(0.0)$ & \\
\hline $\mathrm{BCLC}-\mathrm{n}(\%)$ & & & - \\
\hline A & $15(50.0)$ & - & \\
\hline B & $12(40.0)$ & - & \\
\hline C & $03(6.7)$ & - & \\
\hline $\mathrm{D}$ & $02(3.3)$ & - & \\
\hline $\mathrm{BMI}($ mean $\pm \mathrm{SD})$ & $25.5 \pm 4.3$ & $28.4 \pm 6.5$ & 0.235 \\
\hline Ascites - n (\%) & $08(25.8)$ & $06(12.5)$ & 0.062 \\
\hline
\end{tabular}

\# Statistically significant association through adjusted residual test at $5 \%$ significance; SD: standard deviation; HCC: hepatocellular carcinoma; CI: cirrhosis patients; CHILD: Child-Turcote-Pugh; BCLC: Barcelona Clinic Liver Cancer; BMI: body mass index

TABLE 2. Biochemical nutritional markers assessment according to the normality values: comparison between groups

\begin{tabular}{|c|c|c|c|c|c|c|c|}
\hline \multirow[b]{2}{*}{ Variables* } & \multicolumn{3}{|c|}{ Group HCC n (\%) } & \multicolumn{3}{|c|}{ Group CI n (\%) } & \multirow[b]{2}{*}{$P$-value } \\
\hline & $\begin{array}{l}\text { Below } \\
\text { ULN }\end{array}$ & Normal & $\begin{array}{l}\text { Above } \\
\text { ULN }\end{array}$ & $\begin{array}{l}\text { Below } \\
\text { ULN }\end{array}$ & Normal & $\begin{array}{c}\text { Above } \\
\text { ULN }\end{array}$ & \\
\hline Glucose & $0(0.0)$ & $11(42.3)$ & $15(57.7)$ & $0(0.0)$ & $22(47.8)$ & $24(52.2)$ & 0.837 \\
\hline Total cholesterol & $0(0.0)$ & $22(88.0)$ & $03(12.0$ & $0(0.0)$ & $37(82.2)$ & $08(17.8)$ & 0.735 \\
\hline HDL & $17(70.8)$ & $07(29.2)$ & $0(0.0)$ & $20(44.4)$ & $25(55.6)$ & $0(0.0)$ & 0.066 \\
\hline Triglycerides & $0(0.0)$ & $23(92.0)$ & $02(8.0)$ & $0(0.0)$ & $41(91.1)$ & $04(8.9)$ & 1.000 \\
\hline Total proteins & $0(0.0)$ & $19(90.5)$ & $02(9.5)$ & $0(0.0)$ & $37(84.1)$ & $07(15.9)$ & 0.706 \\
\hline Albumin & $13(43.3)$ & $17(56.7)$ & $0(0.0)$ & $15(31.3)$ & $33(68.8)$ & $0(0.0)$ & 0.401 \\
\hline Creatinine & $0(0.0)$ & $28(90.3)$ & $03(9.7)$ & $0(0.0)$ & $40(83.3)$ & $08(16.7)$ & 0.513 \\
\hline Uric acid & $0(0.0)$ & $16(66.7)$ & $08(33.3)$ & $0(0.0)$ & $36(81.8)$ & $08(18.2)$ & 0.268 \\
\hline Transferrin saturation & $03(13.0)$ & $10(43.5)$ & $10(43.5)$ & $08(18.2)$ & $27(61.4)$ & $09(20.5)$ & 0.139 \\
\hline Iron ${ }^{\#}$ & $05(21.7)$ & $08(34.8)$ & $10(43.5)$ & $04(9.1)$ & $32(72.7)$ & $08(18.2)$ & 0.011 \\
\hline Ferritin ${ }^{\#}$ & $02(8.7)$ & $09(39.1)$ & $12(52.2)$ & $03(6.8)$ & $35(79.5)$ & $06(13.6)$ & 0.002 \\
\hline Hematocrit & $17(54.8)$ & $14(45.2)$ & $0(0.0)$ & $16(33.3)$ & $32(66.7)$ & $0(0.0)$ & 0.097 \\
\hline Hemoglobin & $12(38.7)$ & $16(51.6)$ & $03(9.7)$ & $11(22.9)$ & $35(72.9)$ & $02(4.2)$ & 0.146 \\
\hline Copper & $0(0.0)$ & $20(90.9)$ & $02(9.1)$ & $0(0.0)$ & $35(81.4)$ & $08(18.6)$ & 0.474 \\
\hline Zinc & $07(31.8)$ & $14(63.6)$ & $01(4.5)$ & $14(31.8)$ & $27(61.4)$ & $03(6.8)$ & 0.934 \\
\hline Magnesium & $0(0.0)$ & $24(100)$ & $0(0.0)$ & $01(2.2)$ & $44(97.8)$ & $0(0.0)$ & 1.000 \\
\hline Vitamin B12 & $0(0.0)$ & $17(73.9)$ & $06(26.1)$ & $01(2.3)$ & $36(81.8)$ & $07(15.9)$ & 0.485 \\
\hline Folic acid & $0(0.0)$ & $18(78.3)$ & $05(21.7)$ & $0(0.0)$ & $33(75.0)$ & $11(25.0)$ & 1.000 \\
\hline
\end{tabular}

\# Statistically significant association through adjusted residual test at $5 \%$ significance. ULN: upper limit of normal; HCC: hepatocellular carcinoma; CI: cirrhosis patients. 
Regarding the glucose serum levels, it was observed that it was above the limits of normality, in similar proportion, in both groups (Table 2) $(P=0.837)$, and no difference was found in the mean values between the studied groups (Table 3 ).

TABLE 3. Biochemical nutritional markers assessment according to the mean and median values: comparison between groups

\begin{tabular}{lccc}
\hline Variables* & Group HCC & Group CI & $\boldsymbol{P}$-value \\
\hline Glucose & $109(93-122)$ & $102(92-131)$ & 0.995 \\
Total cholesterol & $144.6 \pm 40.1$ & $153.9 \pm 45.6$ & 0.398 \\
HDL & $36.2 \pm 12.8$ & $49.7 \pm 14.6$ & $<0.001$ \\
Triglycerides & $104(86.5-122)$ & $75(65-100)$ & 0.003 \\
Total proteins & $7.45 \pm 0.68$ & $7.33 \pm 0.70$ & 0.515 \\
Albumin & $3.50 \pm 0.67$ & $3.79 \pm 0.60$ & 0.056 \\
Creatinine & $1.12 \pm 0.43$ & $1.06 \pm 0.28$ & 0.457 \\
Uric acid & $6.18 \pm 1.98$ & $5.38 \pm 1.60$ & 0.077 \\
Transferrin saturation & $39(21-65)$ & $32.5(22.3-49)$ & 0.468 \\
Iron" & $136(79-168)$ & $101(76-144)$ & 0.373 \\
Ferritinn & $351(122-593)$ & $118(68-256)$ & 0.009 \\
Hematocrit & $36.2 \pm 7.0$ & $39.2 \pm 4.5$ & 0.042 \\
Hemoglobin & $12.5 \pm 2.6$ & $13.4 \pm 1.6$ & 0.092 \\
Copper & $123.7 \pm 35.1$ & $132.5 \pm 32.1$ & 0.314 \\
Zinc & $5.88 \pm 0.89$ & $5.93 \pm 1.22$ & 0.859 \\
Magnesium & $1.96 \pm 0.20$ & $1.99 \pm 0.22$ & 0.513 \\
Vitamin B12 & $755 \pm 246$ & $702 \pm 271$ & 0.432 \\
Folic Acid & $13.1 \pm 5.7$ & $13.7 \pm 4.6$ & 0.667 \\
\hline * Described by mean \pm standard deviation or median (percentiles $25-75)$ & \\
\# Statistically significant association through adjusted residual test at 5\% significance \\
HCC: hepatocellular carcinoma; CI: cirrhosis patients.
\end{tabular}

HDL cholesterol was decreased in patients from both HCC and CI groups $(P=0.066)$ (Table 2$)$. The mean serum levels were significantly lower $(P<0.001)$ in group HCC in contrast to group CI $(36.2 \times 49.7 \mathrm{mg} / \mathrm{dL})$ (Table 3$)$.

The triglycerides serum levels were within normality in both groups (Table 2), although they presented lower mean values in group CI $(104 \times 75 \mathrm{mg} / \mathrm{dL})(P=0.003)($ Table 3$)$.
The iron levels in patients from group HCC were higher than in patients from group CI $(P=0.011)$ (Table 2$)$. The mean values in groups HCC and CI were, respectively, $136 \mu \mathrm{g} /$ $\mathrm{dL}$ and $101 \mu / \mathrm{dL}$, with no statistically significant difference $(P=0.373)$ (Table 3).

The ferritin levels were higher in patients from group HCC than in those from group CI $(P=0.002)$ (Table 2$)$. There was a statistically significant difference between the mean values when comparing HCC to CI $(P=0.009)$ (Table 3$)$.

The hematocrit was below normal in $17(54.8 \%)$ patients from group HCC and in 16 (33.3\%) from group CI (Table 2), with no statistically significant difference. However, patients from group $\mathrm{HCC}$ presented lower mean hematocrit than patients from group CI $(P=0.042)$ (Table 3$)$.

No statistically significant differences were found between the groups in the other assessed biochemical parameters.

Evaluating the association between CI staging in group HCC and the biochemical parameters, it was observed that the higher the CTP scoring in group HCC, the lower the mean values of albumin $(P<0.001)$, hematocrit $(P=0.006)$, hemoglobin $(P=0.007)$ and zinc $(P=0.023)$. When analyzing the association between HCC staging through BCLC classification and the biochemical parameters, it was observed that only hematocrit $(P=0.004)$ and hemoglobin $(P=0.004)$ were decreased in patients with more severe disease. Higher uric acid serum levels $(P=0.011)$ were found in patients with more advanced BCLC. When evaluating the association between CTP in group CI and the biochemical parameters, the total cholesterol $(P=0.037)$, albumin $(P=0.002)$, creatinine $(P=0.003)$ and zinc levels $(P=0.008)$ presented negative correlation. Lastly, significant positive association was found between the highest score in CTP classification in group CI and increased transferrin saturation $(P=0.002)$, iron $(P=0.006)$ and $\mathrm{B} 12$ vitamin levels $(P=0.016)$ (Table 4$)$.

TABLE 4. Association between the biochemical parameters and disease severity per studied group

\begin{tabular}{lccc}
\hline \multirow{2}{*}{ Variables } & \multicolumn{2}{c}{ Group HCC } & Group CI \\
\cline { 2 - 4 } & $\mathbf{r}_{\mathbf{s}}(\boldsymbol{P})$ & $\begin{array}{c}\text { BCLC } \\
\mathbf{r}_{\mathbf{s}}(\boldsymbol{P})\end{array}$ & $-0.019(0.901)$ \\
$\mathbf{r}_{\mathbf{s}}(\boldsymbol{P})$ & $-0.36(0.517)$ & $-0.316(0.037)^{\#}$ \\
Glucose & $0.143(0.487)$ & $0.100(0.642)$ & $-0.003(0.985)$ \\
Total cholesterol & $-0.055(0.795)$ & $-0.363(0.089)$ & $-0.166(0.280)$ \\
HDL & $-0.279(0.186)$ & $0.033(0.879)$ & $-0.258(0.095)$ \\
Triglycerides & $-0.066(0.754)$ & $-0.052(0.829)$ & $-0.443(0.002)^{\#}$ \\
Total proteins & $-0.352(0.117)$ & $-0.310(0.102)$ & $-0.430(0.003)^{\#}$ \\
Albumin & $-0.617(<0.001)^{\#}$ & $0.326(0.079)$ & $-0.237(0.126)$ \\
Creatinine & $0.045(0.808)$ & $0.520(0.011)^{\#}$ & $0.459(0.002)^{\#}$ \\
Uric acid & $0.108(0.615)$ & $-0.218(0.331)$ & $0.412(0.006)^{\#}$ \\
Transferrin saturation & $0.142(0.518)$ & $-0.284(0.200)$ & $0.091(0.563)$ \\
Iron & $-0.043(0.847)$ & $0.081(0.719)$ & $-0.256(0.082)$ \\
Ferritin & $0.182(0.406)$ & $-0.507(0.004)^{\#}$ & $-0.226(0.127)$ \\
Hematocrit & $-0.484(0.006)^{\#}$ & $-0.513(0.004)^{\#}$ & $-0.118(0.455)$ \\
Hemoglobin & $-0.472(0.007)^{\#}$ & $0.358(0.111)$ & $-0.398(0.008)^{\#}$ \\
Copper & $-0.210(0.349)$ & $0.047(0.838)$ & $-0.201(0.191)$ \\
Zinc & $-0.483(0.023)^{\#}$ & $0.250(0.249)$ & $0.366(0.016)^{\#}$ \\
Magnesium & $0.012(0.954)$ & $-0.092(0.683)$ & $0.152(0.330)$ \\
Vitamin B12 & $0.292(0.177)$ & $-0.039(0.863)$ & \\
Folic acid & $-0.219(0.315)$ & & \\
\hline
\end{tabular}

HCC: hepatocellular carcinoma; CI: cirrhosis patients; CTP: Child-Turcot Pugh score; BCLC: Barcelona Clinic Liver Cancer; $r$ : Spearman's correlation coefficient 


\section{DISCUSSION}

Malnutrition in liver cirrhosis patients, including those with $\mathrm{HCC}$, has a multifactorial origin, which might result from either insufficient food intake or factors related to deficient digestion and intestinal absorption. It might also be associated with protein-losing enteropathies, metabolic disorders and constant restrictive dietetic approaches to which these patients are subjected ${ }^{(34)}$.

Metabolic disorders, such as alterations in the metabolism of carbohydrates (insulin resistance); proteins, due to increased need and decreased absorption with reduction in hepatic synthesis; and fat, by lipolysis increase and lipid oxidation $^{(34)}$, as well as hypermetabolism, which occurs in $16 \%-34 \%$ of patients with chronic hepatic disease ${ }^{(32,34)}$, can favor malnutrition development.

For many years, malnutrition has been related to worse clinical evolution and higher incidence of complications in liver cirrhosis patients such as ascites, hepatic encephalopathy and infections, hepatorenal syndrome and diabetes mellitus. It is considered a risk factor for short and long-term morbidity and mortality $(13,25,33,34)$.

On the other hand, nutritional assessment in this population is difficult, given that the assessment methods can be masked by water retention, edema and ascites. Many traditionally measured parameters, such as weight and biochemical evaluation, constantly vary according to the hepatic disease severity, regardless of the nutritional state $e^{(9)}$. There is no clear distinction between the laboratorial alterations caused by malnutrition and the ones found in more advanced stages of chronic hepatic disease ${ }^{(23)}$.

So far, there is no defined gold-standard for nutritional assessment in liver cirrhosis patients, and the studies that assess biochemical nutritional alterations in liver cirrhosis patients are still $\mathrm{few}^{(8)}$.

In this study, both group of patients included overweight individuals, reinforcing the limitation to evaluate nutritional aspects in this population. A few patients presented ascites (similar proportion in both groups), therefore not interfering tendentiously with the results.

Among the patients assessed, there was a predominance of CTP-A in both groups. This finding was probably due to the fact that the collection was carried out in an ambulatory, where more stable patients are evaluated. The fact that group HCC is composed by younger patients is in accordance with the literature, as is the predominance of male patients in both groups ${ }^{(12)}$.

Regarding carbohydrate metabolism, studies have shown that CI present higher rates of diabetes mellitus and insulin resistance than those without the disease, as well as a higher risk of developing HCC. The mechanisms that might relate diabetes mellitus to carcinogenesis in chronic infection by $\mathrm{HCV}$ are still unknown ${ }^{(26,43)}$. The present study corroborates such results, since more than half of the patients in both assessed groups presented increases in glucose levels.

Correlation between the CTP score in liver cirrhosis patients and lipid serum levels has been observed, suggesting that this parameter can be used to estimate the prognosis of liver cirrhosis patients ${ }^{(19)}$. Malignant neoplasia carriers present increased triglycerides, glycerol and free fatty acids serum levels as they loose adipose tissue, characterizing a state of lipolysis and lipid peripheral synthesis reduction ${ }^{(40)}$. HCC development is also related to the reduction in triglycerides and total decrease of cholesterol serum levels, with negative correlation between the size of the tumor and the triglycerides levels ${ }^{(19)}$. Some authors have observed reductions in the total cholesterol or HDL serum levels in liver cirrhosis patients ${ }^{(14)}$ and in $\mathrm{HCC}^{(19)}$. Likewise, increased triglyceride levels in this population have been reported ${ }^{(40)}$. In the present study, the total cholesterol levels presented negative correlation with the CTP score in group CI, while the HDL cholesterol was decreased in group HCC. The triglyceride serum levels were within normality in most patients from both groups, though they presented lower mean values in group CI. Different results showing reduction in the triglyceride and total cholesterol levels in HCC patients have also been described ${ }^{(19,21)}$. Racial disparities and dietary differences are possible causes for the difference in lipid metabolism between the cited studies. Some studies assess the prognostic importance of lipids in liver cirrhosis patients, observing that lower serum levels related to more advanced hepatic disease and higher mortality rates ${ }^{(14,35)}$

Regarding the protein metabolism assessment, some authors report negative correlation between the albumin levels and CTP score, morbidity and mortality rates ${ }^{(23,29)}$, while others show that patients classified as CTP-A presented albumin levels within the reference normality rate ${ }^{(23)}$. Increase in uric acid serum levels in patients with higher TNM classification (Classification of Malignant Tumours ${ }^{(37)}$ has been observed, in addition to positive correlation with mortality in liver cirrhosis patients ${ }^{(1,22)}$. The present study corroborates the literature, observing negative correlation between albumin and CTP score in both groups, creatinine and CTP in group CI, and positive correlation between the uric acid and BCLC classification. Despite the limitation resulting from its extended half-life, interfering in the detection of acute alterations of the nutritional state, and the alterations for several other non-nutritional reasons, the albumin serum levels are strongly related to morbidity increase and mortality in liver cirrhosis patients ${ }^{(21)}$. Moreover, albumin and creatinine serum levels are affected by hepatic disorder and are, therefore, less appropriate to be used as independent markers of the nutritional state ${ }^{(39)}$. In this way, the correlation between the CTP score with albumin levels was already expected and has little relevance in the nutritional assessment of liver cirrhosis patients.

In regards to the metabolism of vitamins and minerals, several studies have found different results in micronutrients serum levels. Some ${ }^{(11,28,30,38)}$ affirm that there are increases in serum transferrin, iron and ferritin saturation levels, positively correlated with the presence of $\mathrm{HCV}$, cirrhosis and HCC, especially in more advanced stages of the diseases. However, other authors have not observed alterations in the iron levels ${ }^{(4)}$ or report reduction in liver cirrhosis and HCC 
patients ${ }^{(6)}$. The present study showed an increase in the serum levels or positive correlation with CTP or BCLC in transferrin (in CI group), iron (in CI and HCC group) and ferritin saturation (in HCC group), which is in accordance with the literature $^{(11,28,30,38)}$. A possible explanation is the fact that the iron absorbance through transferrin receptors is higher in hepatocellular carcinoma than in a normal liver, making the transferrin a marker of the presence of $\mathrm{HCC}^{(28)}$.

Hematocrit and hemoglobin can also negatively correlate with the CTP score. Although hemoglobin and hematocrit are independent from the hepatic metabolism, they can be altered in cases of severe portal hypertension followed by splenomegaly and hypersplenism, as well as in the presence of digestive bleeding ${ }^{(32)}$.

A study performed in 2010 found inverse correlation between hemoglobin and hematocrit with cirrhosis severity assessed by the CTP score ${ }^{(41)}$. In the present study, a decrease in the serum levels or negative correlation with CTP and BCLC in the hematocrit and hemoglobin values in patients with $\mathrm{CI}$ and $\mathrm{HCC}$ was observed.

Reduction in the zinc serum levels has been reported in the presence of $\mathrm{HCV}$, cirrhosis and HCC, especially in more severe patients ${ }^{(17,24,27)}$. Some authors have observed significant reduction in the zinc levels in patients with chronic hepatitis, cirrhosis and HCC, suggesting that it should be used as a HCC prognosis biomarker ${ }^{(17,27)}$. However, significant reduction of the plasmatic levels of this mineral appears only in cases of severe nutritional deficiencies ${ }^{(15)}$. Some authors have suggested that zinc supplementation in liver cirrhosis patients with low plasmatic zinc levels can decrease the cumulative incidence of HCC, and improve long-term outcome ${ }^{(24)}$. The data found herein regarding serum zinc corroborates the literature.
Studies suggest that B12 vitamin has a hepatoprotective effect on liver cirrhosis patients ${ }^{(18)}$ and that the dosage of the serum levels could be used as a prognostic marker for followup of HCC patients with regular alpha-fetoprotein levels ${ }^{(20)}$. However, there are conflicting studies in the literature, with authors that have observed reduction in B12 vitamin levels in HCC patients ${ }^{(22)}$. Confirming the differing findings within the literature, the present study observed statistically significant positive correlation between the highest CTP score in group $\mathrm{CI}$ and increase in B12 vitamin levels.

Some authors suggest that other biochemical parameters such as calcium, copper, magnesium, folate, vitamin $\mathrm{K}$, and antioxidants can be used in the joint assessment of the nutritional and metabolic state ${ }^{(3,4,17,22)}$. Nevertheless, statistically significant differences were not found between the groups in the other biochemical parameters assessed herein (copper, magnesium and folate).

As we can see in the present study, many biochemical parameters (total cholesterol, albumin, creatinine, uric acid, transferrin saturation, iron, hematocrit, hemoglobin, B12 vitamin and zinc) may be useful in identifying patients with a more advanced liver disease (CI with or without $\mathrm{HCC}$ ). In the same way, CI with HCC may present more alterations in the evaluation of iron metabolism tests (hematocrit, iron and ferritin levels) and lipid metabolism (HDL cholesterol, tryglicerides) than those CI without HCC.

In conclusion, considering the alterations in macro and micronutrients metabolism in $\mathrm{CI}$ and $\mathrm{HCC}$, and that the classic nutritional assessment methods present limitations for this population, the biochemical assessments are valid to complement the diagnosis of the nutritional state in a quick and practical way, also contributing for CI and $\mathrm{HCC}$ monitoring.

Port GZ, Oliveira K, Soldera J, Tovo CV. Perfil nutricional bioquímico de pacientes portadores de cirrose com carcinoma hepatocelular. Arq Gastroenterol. 2014,51(1):10-5.

RESUMO - Contexto - Pacientes cirróticos portadores de carcinoma hepatocelular apresentam alterações nutricionais e metabólicas, com impacto negativo no prognóstico. Objetivo - Observar o perfil dos macro e micronutrientes em pacientes cirróticos com e sem carcinoma hepatocelular e sua relação com escore de Child-Turcot-Pugh e estadiamento através do escore do grupo Barcelona Clinic Liver Cancer. Métodos - Estudo transversal analítico. Avaliados exames laboratoriais de 31 pacientes com carcinoma hepatocelular e 48 com pacientes cirróticos pelo vírus da hepaite C (CI-HCV). Resultados - A avaliação metabólico-nutricional de portadores de cirrose-HCV e carcinoma hepatocelular mostrou-se alterada em relação ao perfil lipídico (colesterol total, HDL e triglicerídeos), proteico (albumina, creatinina e ácido úrico), ferro (saturação da transferrina, ferro e ferritina), hematócrito e hemoglobina, zinco e vitamina B12. O diagnóstico de carcinoma hepatocelular foi relacionado com piores resultados de colesterol HDL, hematócrito e aumento de ferro e ferritina. Houve correlação entre marcadores bioquímicos nutricionais e a classificação de ChildTurcot-Pugh e com o estadiamento Barcelona Clinic Liver Cancer. Conclusão - Considerando a existência de alterações no metabolismo dos macro e micronutrientes nos pacientes cirróticos com e sem carcinoma hepatocelular e sua relação com o prognóstico das doenças, a avaliação bioquímica é válida para complementar o diagnóstico do estado nutricional de maneira rápida e prática.

DESCRITORES - Cirrose hepática. Carcinoma hepatocelular. Desnutrição. Avaliação nutricional. Hepacivirus. 


\section{REFERENCES}

1. Afzali A, Weiss NS, Boyko EJ, Ioannou GN Association Between Serum Uric Acid Level and Chronic Liver Disease in the United States. Hepatology. 2010;52:578-89.

2. American Diabetes Association (ADA). Blood Glucose Level. Available from: http//:www.diabetes.org.

3. Bae HM, Lee JH, Yoon JH, Kim YJ, Heo DS, Lee HS. Protein induced by vitamin $\mathrm{k}$ absence or antagonist-ii production is a strong predictive marker for extrahepatic metastases in early hepatocellular carcinoma: a prospective Evaluation. BMC Cancer. 2011; 435:1-11

4. Boige V, Castera L, de Roux N, Ganne-Carrie N, Ducot B, Pelletier G, Beaugrand M, Buffet C. Lack of association between HFE gene mutations and hepatocellular carcinoma in patients with cirrhosis. Gut. 2003;52:1178-81.

5. Bruix J, Sherman M. Management of hepatocellular carcinoma: an up to date Hepatology. 2011;53:1020-2.

6. Buyukasik NS, Nadir I, Akin FE, Cakal B, Kav T, Ersoy O, Buyukafiik Y. Serum iron parameters in cirrhosis and chronic hepatitis: Detailed description. Turk J Gastroenterol. 2011;22:606-11.

7. Cabré E, Gassull MA. Nutritional and metabolic issues in cirrhosis and liver transplantation. Curr Opin Clin Nutr Metab Care. 2000;3:345-54.

8. Fernandes AS, Bassani L, Nunes FF, Aydos MED, Alves AV, Marroni CA. Nutritional assessment in patients with cirrhosis. Arq Gastr. 2012;49:19-27.

9. Figueiredo FA, Dickson ER, Pasha T, Kasparova P, Therneau T, Malinchoc M, DiCecco S, Francisco-Ziller N, Charlton M. Impact of nutritional status on outcome after liver transplantation. Transplantation. 2000;70:1347-52.

10. Fleming KA, McGee J. Alcohol induced liver disease. Journal of Clinical Pathology. 1984;37:721-33

11. Franchini M, Targher G, Capra F, Montagnana M, Lippi G. The effect of iron depletion on chronic hepatitis C virus infection. Hepatol Int. 2008;2:335-40.

12. Gonçalves CS, Pereira FEL, Gayotto LCC. Hepatocellular carcinoma in Brazil: report of a national survey (Florianopolis, SC, 1995). Rev Inst Med Trop S Paulo. 1997;39:165-70.

13. Gunsar F, Riamondo ML, Jones S, Terreni N, Wong C, Patch D, Sabin C, Vurroughs AK. Nutritional status and prognosis in cirrhotic patients. Aliment Pharmacol Ther. 2006;24:563-72.

14. Habib A, Mihas AA, Abou-Assi SG, Williams LM, Gavis E, Pandak WM, Heuman DM. High-density lipoprotein cholesterol as an indicator of liver function and prognosis in noncholestatic cirrhotics. Clin Gastroenterol Hepatol. 2005; 3:286-91.

15. Hambige M. Biomarkers of Trace Mineral Intake and Status. J Nutr. 2003;133: 948-55.

16. Hehir DJ, Jenkins RL, Bistrian BR, Blackburn GL. Nutrition in patients undergoing orthotopic liver transplant. J Parenter Enteral Nutr. 1985;9:695-700.

17. Huang Y, Li LZ, Zhang CZY, Yi C, Liu LL, Zhou X, Xie GB, Cai MY, Li Y, Yun JP. Decreased expression of zinc-alpha2-glycoprotein in hepatocellular carcinoma associates with poor prognosis. Journal of Translational Medicine. 2012;10:106-21

18. Isoda K, Kagaya N, Akamatsu S, Hayashi S, Tamesada M, Watanabe A, Kobayashi M, TagawaYI, Kondoh M, Kawase M, Yagi K. Hepatoprotective Effect Of Vitamin B12 On Dimethylnitrosamine-Induced Liver Injury. Biol Pharm Bull. 2008;31:309-11.

19. Jiang M, Liu F, Xiong WJ, Zhong L, Xu W, Xu F, Liu YB. Combined MELD and blood lipid level in evaluating the prognosis of decompensated cirrhosis. World $\mathbf{J}$ Gastroenterology. 2010;16:1397-401.

20. Kane SP, Murray-lyon M, Paradinas J, Johnson J, Williams R, Orr H, Kohn J. Vitamin b12 binding protein as a tumour marker for hepatocellular carcinoma. Gut. 1978;19:1105-9.

21. Lieber CS. Nutrição nos distúrbios hepáticos. In: Shils ME, Olson JA, Shike M, Ross AK. Tratado de Nutrição Moderna na saúde e na doença. São Paulo: Manole; 2003. p. 1257-69.
22. Lin CC, Yin MC. B Vitamins Deficiency and Decreased anti-oxidative state in Patients in Liver Cancer. Europe Journal of Nutrition. 2007:46:293-9.

23. Maio R, Dichi JB, Burini RC. Sensibility of anthropometric-laboratory markers of protein-energy malnutrition in cirrhotic patients. Arq Gastroenterol. 2004;41:93-9.

24. Matsuoka S, Matsumura H, Nakamura H, Oshiro S, Arakawa Y, Hayashi J, Sekine N, Nirei K, Yamagami H, Ogawa M, Nakajima N, Amaki S, Tanaka N, Moriyama M. Zinc Supplementation Improves the Outcome of Chronic Hepatitis C and Liver Cirrhosis. J Clin Biochem Nutr. 2003;45:292-303.

25. Mattos AA, Coral GP, Menti E, Valiatti F, Kramer C. Infecção bacteriana no paciente cirrótico. Arq Gastr. 2003;40:11-5.

26. Menezes MO, Tovo CV, Mattos AA. Associação entre a hepatite crônica pelo vírus da hepatite $\mathrm{C}$ (VHC) e diabete melito em pacientes monoinfectados pelo VHC e co-infectados com o vírus da imunodeficiência humana. Revista da AMRIGS 2008;52:17-23

27. Nazari MA, Malayeri SH, Pourhoseingholi MA, Mohebi SR, Zali MR. Evaluation of Zinc Plasma Level in Iranian Cirrhotic Patients due to Hepatitis B and Hepatitis C. Hepatitis Monthly. 2010;10:62-4

28. Pascale RM, De Miglio MR, Muroni MR, Simile MM, Daino L, Seddaiu MA, Pusceddu S, Gaspa L, Calvisi D, Manenti G, Feo F. Transferrin and Transferrin Receptor Gene Expression and Iron Uptake in Hepatocellular Carcinoma in the Rat. Hepatology. 1998;27:452-61.

29. Piquet MA, Ollivier I, Gloro R, Castel H, Tiengou LE, Dao T. Nutritional indices in cirrhotic patients. Nutrition. 2006;22:216-7.

30. Price L, Kowdley K. The role of iron in the pathophysiology and treatment of chronic hepatitis C. Can J Gastroenterology. 2009;23:822-8.

31. Pugh RNH, Murray-Lyon IM, Dawson JL, Pietroni MV, Williams R. Transection of the oesophagus for bleeding oesophageal varices. Br J Surg. 1973;60:646-9.

32. Ritter L, Gazzola J. Avaliação nutricional no paciente cirrótico: uma abordagem objetiva, subjetiva ou multicompartimental? Arq Gastr. 2006;43:66-70.

33. Rosa H, Silvério AO, Perini RF, Arruda CB. Bacterial infection in cirrhotic patients and its relationship with alcohol. Gastroenterology. 2000;95:1290-3.

34. Sam J, Nguyen GC. Protein-calorie malnutrition as a prognostic indicator of mortality among patients hospitalized with cirrhosis and portal hypertension. Liver International. 2009;29:1396-402.

35. Selcuk H, Uruc I, Temel MA, Ocal S, Huddam B, Korkmaz M, Unal H, Kanbay M, Savas N, Gur G, Yilmaz U, Haberal M. Factors prognostic of survival in patients awaiting liver transplantation for end-stage liver disease. Dig Dis Sci. 2007;52:3217-23.

36. Siriboonkoom W, Gramlich L. Nutrition and chronic liver disease. Can J Gastroenterol. 1998;12:201-7.

37. Sobin LH, Wittekind C. TNM Classification of Malignant Tumours. New Jersey: John Wiley \& Sons; 2002

38. Tan MGK, Kumarasinghe MP, Wang SM, Lucien LPJ, Aw SE, Hui KM. Modulation of iron-regulatory genes in human hepatocellular carcinoma and its physiological consequences. Exp Biol Med. 2009;234:693-702.

39. Tandon P, Gramlich L, Lipman TO, Bonis PAL. Nutritional assessment in chronic liver disease. Up ToDate, 2010.

40. Tisdale MJ. Cancer anorexia and cachexia. Nutrition 2001;17:438-42

41. Vulcano, DSB. Avaliação dos indicadores nutricionais em hepatopatas crônicos e a relação com a etiologia e gravidade da doença. [Dissertação de mestrado]. Botucatu: Faculdade de Medicina de Botucatu, Universidade Estadual Paulista; 2010.

42. World Health Organization (WHO). Physical status: the use and interpretation of anthropometry. Geneva. WHO, 1995 (WHO - technical report series 854).

43. Zhao J, Zhao Y, Wang H, Gu X, Ji J, Gao C. Association between metabolic abnormalities and HBV related hepatocellular carcinoma in Chinese: A cross-sectional study. Nutrition Journal. 2011;10:1-8.

Received 24/8/2013 Accepted 25/10/2013 